\title{
Environment Affects White Drupelet Disorder Expression on Three Blackberry Cultivars in South Mississippi
}

\author{
Eric T. Stafne ${ }^{1,4,8}$, Amir Rezazadeh ${ }^{2,5}$, Melinda Miller-Butler ${ }^{3,6}$, \\ and Barbara J. Smith ${ }^{3,7}$
}

ADDITIONAL INDEX wORDs. anthocyanin, firmness, soluble solids concentration, titratable acidity

Summary. White drupelet disorder (WDD) is a problem that occurs during the ripening stage in some blackberry ( $R u b u s$ subgenus $R u b u s$ ) cultivars. Although berries affected with a few white drupelets may taste fine, they are unpleasant aesthetically, and this may lead to negative consumer perceptions and economic ramifications. During 2 years of observational studies and field trials (2016 and 2017), we evaluated changes in three susceptible cultivars in Mississippi affected by WDD. 'Chickasaw', 'Kiowa', and 'Sweetie Pie' berries were harvested twice per week and assessed for WDD. Weather conditions differed substantially during harvest in 2016 and 2017, with 2017 being cooler and rainier which resulted in a lower incidence of WDD. Compared with 2016, in 2017, the overall percentage of berries exhibiting WDD dropped from $22 \%$ to $12 \%$ for 'Sweetie Pie', $6 \%$ to $3 \%$ for 'Chickasaw', and $8 \%$ to $3 \%$ for 'Kiowa'. The soluble solids concentration was highest in 'Sweetie Pie', $11.9 \%$ and $9.5 \%$ for 2016 and 2017, respectively. For all cultivars examined, the soluble solids concentration of extracted white drupelets was substantially lower than regular drupelets. The value for skin break force for white drupelets was higher than that for black drupelets, $0.99 \mathrm{~N}$ vs. $0.29 \mathrm{~N}$, respectively. In 2017 , an about $30 \%$ shadecloth treatment had a significantly positive impact by decreasing WDD symptoms in all cultivars by $63 \%$ when compared with non-shaded plants, but soluble solids concentration was lower. Our results indicate that rain and shadecloth decrease symptoms of WDD. Therefore, growers may be able to use overhead irrigation and shade to reduce WDD symptoms.

$\mathrm{W}$

DD is a problem in blackberry production, especially in regions where high temperature is experienced during fruit ripening (Bolda, 2009). WDD in blackberries is a tan-to-white discoloration of one to many drupelets on the fruit. Several possible causes have

The project was funded through a Specific Cooperative Agreement between Mississippi State University and the U.S. Department of Agriculture, Agricultural Research Service, supported by the Mississippi Agricultural, Forestry, and Experiment Station, and Mississippi State University Extension Service. This material is based on the work that is supported by the National Institute of Food and Agriculture, U.S. Department of Agriculture, Hatch project under accession number 0232036 .

${ }^{1}$ Coastal Research and Extension Center, Mississippi State University, Poplarville, MS 39470

${ }^{2}$ Mississippi State University, Poplarville, MS 39470

${ }^{3}$ U.S. Department of Agriculture, Agricultural Research Service, Thad Cochran Southern Horticultural Laboratory, Poplarville, MS 39470

${ }^{4}$ Associate Extension and Research Professor.

${ }^{5}$ Horticulturist.

${ }^{6}$ Former Biological Science Lab Technician.

${ }^{7}$ Research Plant Pathologist.

${ }^{8}$ Corresponding author. E-mail: eric.stafne@msstate. edu.

doi: 10.21273/HORTTECH03880-17 been discussed, aside from ultraviolet- $\mathrm{B}$ (UV-B) light or high light intensities, including low humidity, wind, rainfall, stink bugs (Pentatomidae), redberry mites (Acalitus essigi), and interactions of some or all of these (Bolda, 2009; Clark, 2008, 2013; Fernandez, 2012; Ruhl, 2010). It is a problem that does not appear to have a simple, single cause.

Anthocyanin synthesis has been known to be affected by environmental conditions such as growth temperature. Steyn et al. (2004) reported preharvest anthocyanin degradation and a significant decrease in the fruit's market value in both red pear (Pyrus communis) and apple (Malus pumila). Although previous studies have dealt with anthocyanin degradation due to high temperature on plants such as smoketree [Cotinus coggygria (OrenShamir and Levi-Nissim, 1997)] or UV-B on mangrove [Rhizophoru apiculura (Moorthy and Kathiresan, 1997)], there is no information on the effect of these environmental factors causing white drupelets in blackberry.

Blackberry is an excellent source of anthocyanins, which has been reported to contain $67.4-230 \mathrm{mg}$ anthocyanin per $100 \mathrm{~g}$ fresh weight (Benvenuti et al., 2004; Sellappan et al., 2002). Anthocyanins are watersoluble phenolic compounds and part of a large and widespread group of plant flavonoids. Anthocyanins appear in tissues at specific developmental stages, such as juvenile or senescing tissues, or they may be induced with changes in some environmental factors including visible and UV-B radiation, cold temperature, or other signals (Moorthy and Kathiresan, 1997; OrenShamir and Levi-Nissim, 1997). They are the largest group of pigments in plants and are responsible for the red, purple, and black colors in blackberries (Benvenuti et al., 2004).

Some researchers have suggested that WDD may be caused by UV-B radiation or too much visible light (Fernandez, 2012). However, numerous studies have implicated visible light or UV for the induction of flavonoids such as flavones, flavonols, and anthocyanins in a great variety of plant species (Bassman, 2004; Beggs and Wellmann, 1994; Reddy et al., 1994). Other studies suggest that anthocyanins have a photoprotective function against either light-induced photooxidation (Hatier et al., 2013; Hughes et al., 2012; Solovchenko, 2010) or UV-B radiation (Burger and Edwards, 1996; Dodd et al.,

\begin{tabular}{llll}
\hline $\begin{array}{l}\text { Units } \\
\begin{array}{l}\text { To convert U.S. to SI, } \\
\text { multiply by }\end{array}\end{array}$ & U.S. unit & SI unit & $\begin{array}{l}\text { To convert SI to U.S., } \\
\text { multiply by }\end{array}$ \\
\hline 1 & $\%$ & $\mathrm{~g} / 100 \mathrm{~mL}$ & $\mathrm{l}$ \\
10 & $\%$ & $\mathrm{mg} \cdot \mathrm{g}^{-1}$ & 0.1 \\
29.5735 & $\mathrm{fl} \mathrm{oz}$ & $\mathrm{mL}$ & 0.0338 \\
0.3048 & $\mathrm{ft}$ & $\mathrm{m}$ & 3.2808 \\
2.54 & inch $(\mathrm{es})$ & $\mathrm{cm}$ & 0.3937 \\
25.4 & inch $(\mathrm{es})$ & $\mathrm{mm}$ & 0.0394 \\
4.4482 & $\mathrm{lbf}$ & $\mathrm{N}$ & 0.2248 \\
28.3495 & $\mathrm{oz}$ & $\mathrm{g}$ & 0.0353 \\
$\left({ }^{\circ} \mathrm{F}-32\right) \div 1.8$ & ${ }^{\circ} \mathrm{F}$ & ${ }^{\circ} \mathrm{C}$ & $\left({ }^{\circ} \mathrm{C} \times 1.8\right)+32$
\end{tabular}


1998). By contrast, some researchers argue that UV-B radiation can inhibit anthocyanin synthesis or induce degradation, probably via DNA damage or as a result of oxidative stress (Hada et al., 1996; Moorthy and Kathiresan, 1997). Even if any of the aforementioned hypotheses were true in blackberry, it is still difficult to conceive of a mechanism whereby UV-B or visible light exposure would lead to heightened sensitivity in just one or a few random drupelets.

Several cultivars are known to exhibit white drupelets, with 'Apache' often being the most sensitive to WDD (Fernandez, 2012). Almost all of the Arkansas cultivar releases have some degree of the disorder, but many other cultivars also have white drupelets from time to time. This can be a significant problem for growers, especially if a large number of berries (and a large number of drupelets per berry) exhibit WDD. Some recommendations for diminishing white drupelets include overhead irrigation and shading (Spiers et al., 2014). These tactics may work in some areas for some growers but not for all. In Mississippi and Louisiana, blackberry growers often lack the financial resources to shade plots with extensive trellis systems (Takeda et al., 2013) or apply significant amounts of overhead water. Therefore, we implemented a study to examine three cultivars and observe WDD phenomenon in south Mississippi under small-scale production practices.

The objectives of this study were to observe and record physiological and environmental factors that may contribute to the disorder and to describe changes to lessen the impact.

\section{Materials and methods}

Plant material and culture. The study was conducted in 2016 and 2017 at the U.S. Department of Agriculture-Agricultural Research Service (USDA-ARS) Thad Cochran
Southern Horticulture Laboratory in Poplarville, MS (lat. $30^{\circ} 50^{\prime} 25^{\prime \prime} \mathrm{N}$, long. $89^{\circ} 32^{\prime} 03^{\prime \prime} \mathrm{W}$, elevation $97 \mathrm{~m}$, USDA hardiness zone $8 \mathrm{~b}$, average annual extreme minimum temperature from 15 to $20^{\circ} \mathrm{F}$ ). The experimental design was a randomized complete block, with four blocks, each consisting of five plants of each cultivar per block. Three cultivars were used in this study: Chickasaw, Kiowa, and Sweetie Pie. 'Chickasaw' (Ark. $842 \times$ Ark. 1246), released in 1999 (Clark and Moore, 1999), has a genetic background of 'Darrow' $43.75 \%$, 'Brazos' $31.25 \%$, 'Thornfree' $12.5 \%$, and 'Wells Beauty' $12.5 \%$ (based on reported pedigree). 'Kiowa' (Ark. $791 \times$ Ark. 1058), released in 1996 (Moore and Clark, 1996), is composed of 'Brazos' 50\%, 'Thornfree' $18.75 \%$, 'Darrow' 12.5\%, 'Wells Beauty' 12.5\%, and 'Brainerd' $6.25 \%$. 'Sweetie Pie' ('Navaho' $x$ MSUS29), a cultivar from the USDA-ARS (Stringer et al., 2017), is 'Brazos' $43.75 \%$, 'Humble' 25\%, 'Thornfree' 18.75\%, and 'Darrow' $12.5 \%$. Plants were established in 2014 and all were top dressed with $14 \mathrm{~N}-6.1 \mathrm{P}-11.6 \mathrm{~K}$ controlled-release fertilizer (Osmocote; Scotts Co., Marysville, $\mathrm{OH}$ ) at $1.5 \mathrm{oz}$ per plant in Mar. 2016 and 2017. In 2017, for each cultivar, two blocks containing five plants per block were added and covered separately with one layer of about $30 \%$ shadecloth as an additional treatment. Shade percentage was determined by light meter (DLM2; UEi, Beaverton, OR). Daily weather measurements of maximum temperature, minimum temperature, rainfall, and monthly averages (Table 1) were recorded at a nearby weather station (Nimbus Max/Min Digital Thermometer; Sensor Instruments, Bow, NH).

Measurements. Each cultivar was harvested at the ripe stage (dull black) twice per week from 31 May to 30 June in 2016 and from 2 May to
26 June in 2017. All plots were harvested completely, except 'Sweetie Pie' in 2016 when only one-half of the plot was harvested because of an abundance of berries. Harvested berries from each plot were separated into regular berries (no white drupelets) and berries with white drupelets. The total berry weight, regular berry weight, and number of berries with white drupelets were recorded for each plot at each harvest then divided to obtain a proportion by weight of collected berries. Chlorophyll index in the leaves were measured after each harvest with a chlorophyll meter (SPAD-502; Konica Minolta Sensing, Osaka, Japan) in 2017.

Fruit characteristics. Fruit quality including soluble solids concentration, titratable acidity (TA), $\mathrm{pH}$, and firmness were measured. Soluble solids concentration of blackberry juice obtained by crushing a sample of harvested whole berries with hand was determined with a digital hand-held refractometer (Atago, Osaka, Japan) for both regular berries and berries with white drupelets. TA was measured by titration with $0.1 \mathrm{~N}$ of sodium hydroxide $(\mathrm{NaOH})$ to an endpoint of $\mathrm{pH} 8.2$ using a compact titrosampler (862; Metrohm, Herisau, Switzerland). For each harvest, the juice of regular berries and the berries with white drupelets were frozen separately and then were used for TA analysis after the harvest season was completed. In this method, $5 \mathrm{~mL}$ of juice was diluted to $50 \mathrm{~mL}$ with distilled water and titrated against $0.1 \mathrm{M}$ $\mathrm{NaOH}$. Measurements of $\mathrm{pH}$ value were made with a $\mathrm{pH}$-meter (Accumet Excel XL50; Fisher Scientific, Singapore). The texture properties of berry skin were evaluated with a puncture test for each regular and white drupelets using a texture analyzer (TVT 6700 with software TexCalc version 4.0.2.50; Perten Instruments, Hägersten, Sweden). This test was carried out to compare skin mechanical properties of

Table 1. Average maximum temperature, minimum temperature, and rainfall over 2 years during month of blackberry bloom, fruit development, and harvest for Poplarville, MS.

\begin{tabular}{|c|c|c|c|c|c|c|c|c|c|}
\hline \multirow[b]{2}{*}{ Month } & \multicolumn{3}{|c|}{2016} & \multicolumn{3}{|c|}{2017} & \multicolumn{3}{|c|}{ 30-yr avg } \\
\hline & $\begin{array}{l}\text { Avg max } \\
\text { temp }\left({ }^{\circ} F\right)^{z}\end{array}$ & $\begin{array}{l}\operatorname{Avg} \min \\
\operatorname{temp}\left({ }^{\circ} \mathrm{F}\right)\end{array}$ & $\begin{array}{c}\text { Avg } \\
\text { rain (inches) } \\
\end{array}$ & $\begin{array}{l}\text { Avg max } \\
\text { temp }\left({ }^{\circ} F\right)\end{array}$ & $\begin{array}{l}\text { Avg min } \\
\text { temp }\left({ }^{\circ} F\right)\end{array}$ & $\begin{array}{c}\text { Avg rain } \\
\text { (inches) }\end{array}$ & $\begin{array}{l}\text { Avg max } \\
\operatorname{temp}\left({ }^{\circ} \mathrm{F}\right)\end{array}$ & $\begin{array}{l}\text { Avg min } \\
\text { temp }\left({ }^{\circ} \mathrm{F}\right)\end{array}$ & $\begin{array}{c}\text { Avg } \\
\text { rain (inches) }\end{array}$ \\
\hline April & 77.0 & 57.0 & 6.71 & 79.8 & 56.3 & 3.61 & 77.3 & 54.8 & 4.94 \\
\hline May & 82.8 & 61.1 & 3.47 & 81.1 & 60.3 & 11.6 & 84.7 & 63.0 & 4.90 \\
\hline June & 89.5 & 70.1 & 3.46 & 85.2 & 68.3 & 21.1 & 90.1 & 69.4 & 5.69 \\
\hline
\end{tabular}

${ }^{\mathrm{z}}\left({ }^{\circ} \mathrm{F}-32\right) \div 1.8={ }^{\circ} \mathrm{C}, \mathrm{l}$ inch $=2.54 \mathrm{~cm}$ 
regular and white drupelets when attached to the whole berry. Tests were performed using needle probe of $0.5 \mathrm{~mm}$ in diameter at speed test of 10 $\mathrm{mm} \cdot \mathrm{s}^{-1}$ and the berry skin break penetration was recorded in Newtons.

All data to determine percentages were arcsin transformed for statistical analysis and then converted back to display as percentages. Data were analyzed by using analysis of variance $(P<0.05)$ using JMP 9.0 (SAS Institute, Cary, NC) with the fit model procedure. Means were compared by Tukey's honestly significant difference $(P<0.05)$. Correlations were estimated by restricted maximum likelihood using the multivariate procedure and pairwise correlation were tested by Pearson's correlation coefficient.

\section{Results and discussion}

WhITE DRUPELETS. In 2016, there was a difference among the three cultivars in the mean percentage of berries with at least one white drupelet (Table 2). Overall of the harvests, 'Sweetie Pie' had a mean percentage of berries with at least one white drupelet of $22 \%$, whereas 'Chickasaw' and 'Kiowa' each had less than $10 \%$ (6\% and $8 \%$, respectively). In 2017, the overall percentage of berries exhibiting white drupelets dropped to $12 \%$ for 'Sweetie Pie', to $3 \%$ for 'Chickasaw', and to 3\% for 'Kiowa'. Another change observed between 2016 and 2017 was that the amount of harvested WDD fruit was the highest at the beginning of the harvest in 2016 then decreased as the season progressed. In 2017, the opposite trend was observed; white drupelets increased over time and then decreased at week 6. Overall, the mean of the sum of WDD berries harvested was fewer in 2017 than 2016 for all cultivars (Fig. 1). An increase in the number of berries with white drupelets was observed through the harvest season in 2017. This is in contrary to some observations that the white drupelets almost disappear as harvest progresses (Fernandez, 2012).

Correlations of recorded weather conditions (daily maximum temperature, daily minimum temperature, and total rainfall) for 3,5 , and $7 \mathrm{~d}$ before harvest and proportion of berries with WDD were also analyzed. Correlations differed in 2016 and 2017 for plants under no shade conditions.

Table 2. Mean percentage of blackberries with white drupelet disorder for three cultivars in 2 years.

\begin{tabular}{lcc}
\hline & \multicolumn{2}{c}{ Berries with white drupelets $(\%)$} \\
\cline { 2 - 3 } Cultivar & 2016 & 2017 \\
\hline Chickasaw & $6 \mathrm{~b}^{\mathrm{z}}$ & $3 \mathrm{~b}$ \\
Kiowa & $8 \mathrm{~b}$ & $3 \mathrm{~b}$ \\
Sweetie Pie & $22 \mathrm{a}$ & $12 \mathrm{a}$ \\
\hline
\end{tabular}

${ }^{\mathrm{z}}$ Means within a column not followed by the same letter are significantly different as determined by Tukey's honestly significant difference at $P \leq 0.05$.

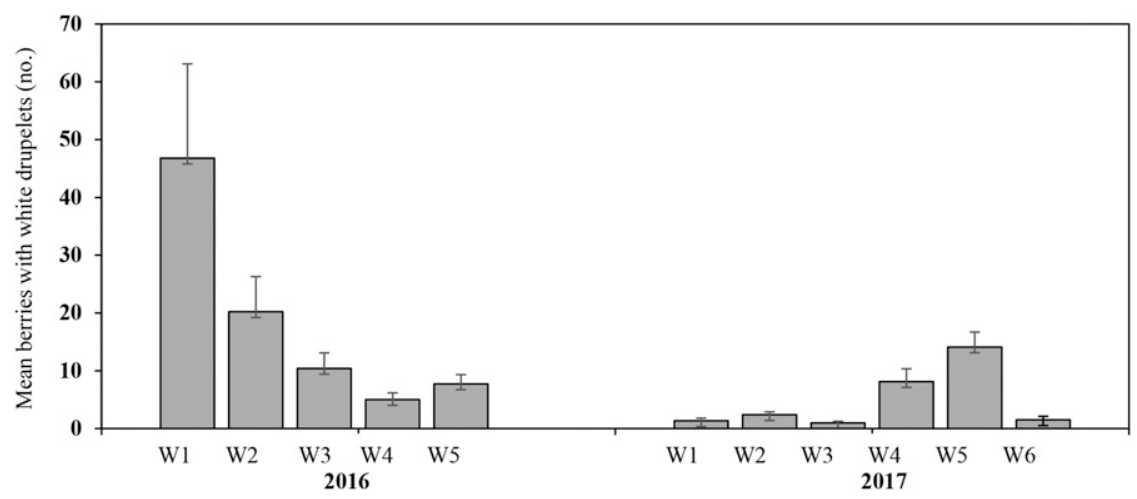

Fig. 1. Mean number of blackberries with white drupelets over three cultivars (Sweetie Pie, Chickasaw, and Kiowa) observed in weekly (W) harvest in 2016 and 2017 harvested in south Mississippi. The data were collected each week for all three cultivars each year. Vertical bars represent the SE.

Daily minimum temperatures for 3,5 , and $7 \mathrm{~d}$ were significant for 'Chickasaw' and 'Sweetie Pie' in 2016, but not in 2017. In 2017, daily maximum temperatures and rainfall were significant for all cultivars. Under shade, only 'Sweetie Pie' WDD was correlated with daily maximum temperatures. It appears that 'Kiowa' may be the least sensitive to environmental changes and 'Sweetie Pie' the most (Table 3).

In 2017 , a shadecloth treatment was added to discover if symptoms diminished under shade, as had been reported previously (Spiers et al., 2014; Takeda et al., 2013). The results clearly indicate that shade treatment had a significantly positive impact by decreasing WDD symptoms overall in cultivars by $63 \% \mathrm{com}$ pared with non-shaded plants. WDD in shaded plants decreased compared with non-shaded plants from $16 \%$ to $7 \%, 5 \%$ to $1 \%$, and $5 \%$ to $1.5 \%$ in 'Sweetie Pie', 'Kiowa', and 'Chickasaw', respectively. No interaction of cultivar and environment was found, meaning that all three cultivars responded the same way to the environmental changes to which they were subjected. Thus, we may be able to infer that any condition that reduces WDD in one cultivar would also do so in another (at least for these three cultivars).

We observed that shade decreased symptoms of WDD. We used 30\% shade, but a higher percent shadecloth may further decrease WDD. Sugar levels also decreased under shade, a potential negative in using shade as a method to reduce WDD. All cultivars responded in a similar manner to the weather conditions. Both 'Chickasaw' and 'Kiowa' had low levels of WDD in both years, whereas 'Sweetie Pie' had $22 \%$ in 2016 when temperatures were higher and rainfall was less, but that fell to $12 \%$ in 2017.

Fruit Quality. The texture of the skin of white drupelets also appeared to be different compared with regular drupelets. Results of puncture analyses showed that drupelet penetration force of black drupelets did not differ significantly among the three cultivars $(P=0.11)$. However, the value for drupelet penetration force for white drupelets was significantly higher than black drupelets, $0.99 \mathrm{~N}$ vs. $0.29 \mathrm{~N}$ $(P<0.0001)$, respectively. The penetration forces reported here are higher than those reported by Salgado and Clark (2016), possibly due to using different equipment, cultivar, and environment. In addition, the response to 
puncture test between cultivars Chickasaw and Sweetie Pie was different. More force was needed to break the skin of white drupelets in 'Chickasaw' compared with 'Sweetie Pie' (0.86 N vs. 1.17 N, respectively).

The soluble solids concentration of extracted white drupelets was substantially lower than normal drupelets (data not shown). Soluble solids concentration from extracted white drupelets and black drupelets was measured on one date in 2017 from 'Sweetie Pie'. Soluble solids concentration of white drupelets was $7.7 \%$ compared with $11.3 \%$ for black drupelets. Soluble solids concentration for whole berries with white drupelets was lower than normal whole berries by $<1 \%$ (Table 4). The soluble solids concentration of regular berries and the berries with white drupelets significantly varied among cultivars in 2016 (Table 4). The soluble solids concentration was higher in 'Sweetie Pie' than the other two cultivars both in regular berries and berries with WDD. In
2017, the soluble solids concentration was lower under the shade treatment during harvest and this was observed for all cultivars. For example, the soluble solids concentration of regular berries and the berries with WDD in shaded plots decreased by $1 \%$ and $2 \%$, respectively. Similarly, with 2016 , soluble solids concentration in 'Sweetie Pie' was higher than 'Kiowa' and 'Chickasaw' in both regular berries and the berries with WDD in 2017.

The weather in 2017 was different from 2016 with weather conditions in 2017 having much cooler high temperatures and far greater rainfall during the harvest period. Twenty-one inches of rain fell during June, four times the normal amount. Fruit quality suffered under these conditions. The soluble solids concentration was reduced by $1 \%$ to $2 \%$ when compared with 2016 . Lower soluble solids concentration was reported by Bergqvist et al. (2001) in two grape (Vitis vinifera) cultivars in response to lower sunlight exposure and lower temperatures.
TA during harvest was affected by shade and cultivar. In general, all cultivars exhibited increased TA in response to shade treatment during harvest (1.25-1.45 g/100 $\mathrm{mL})$. There was a significant difference in TA of berries with only black drupelets (normal) among cultivars. Normal berries contained significantly lower TA $(1.20 \mathrm{~g} / 100 \mathrm{~mL})$ in 'Sweetie Pie' compared with 'Chickasaw' or ' $\mathrm{Ki}$ owa' (Table 4). However, there was not any significant difference in TA in berries with white drupelets among the three cultivars. Shade had a significant impact on acidity of both normal berries and those with white drupelets. The highest acidity was observed on normal berries grown under shade $(1.50 \mathrm{~g} / 100 \mathrm{~mL})$. In general, berries grown under shade had 13\% higher acidity in both normal berries and those with white drupelets (Table 4). The pH was lower in berries harvested from shaded plants compared with no-shade plants [3.05 and 3.10, respectively (Table 4 )]. Therefore, it

Table 3. Pairwise correlations of daily maximum ( $\max )$ temperature, daily minimum (min) temperature, and total rainfall (rain) averaged over 3,5 , and $7 \mathrm{~d}$ before harvest and proportion of blackberries with white drupelets by cultivar, year, and shade.

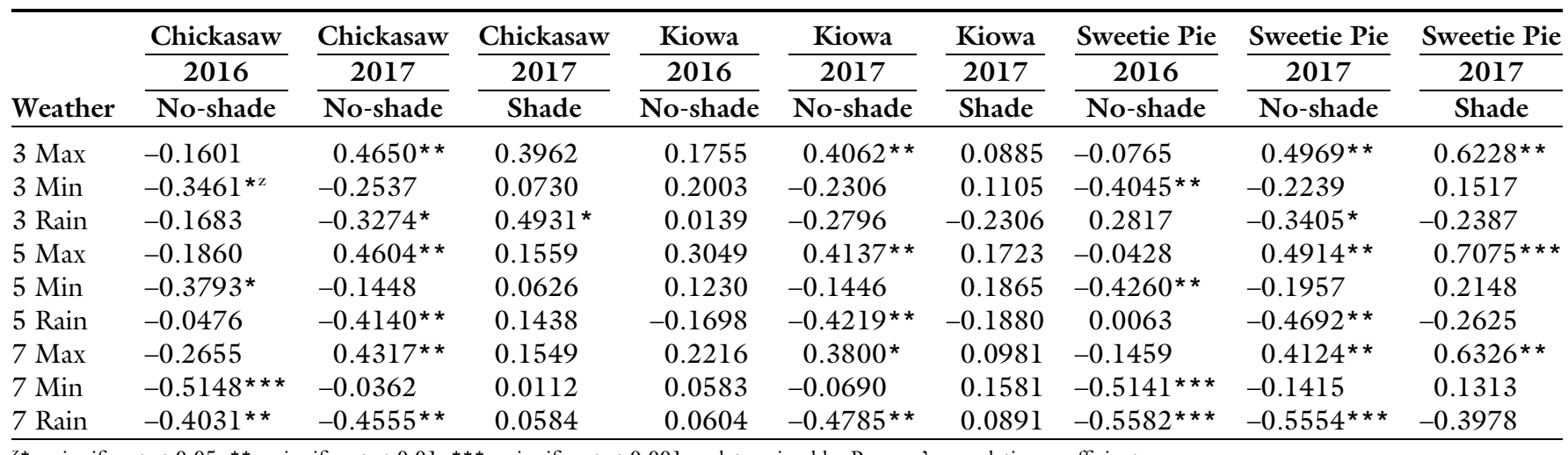

${ }^{\mathrm{z}^{*}}=$ significant at $0.05,{ }^{* *}=$ significant at $0.01,{ }^{* *}=$ significant at 0.001 as determined by Pearson's correlation coefficient.

Table 4. Fruit quality such as soluble solids concentration (SSC), pH, and titratable acidity (TA) of normal (black) and white drupelet disorder (WDD) blackberry fruit from 2016 to 2017 when grown under field conditions and shade.

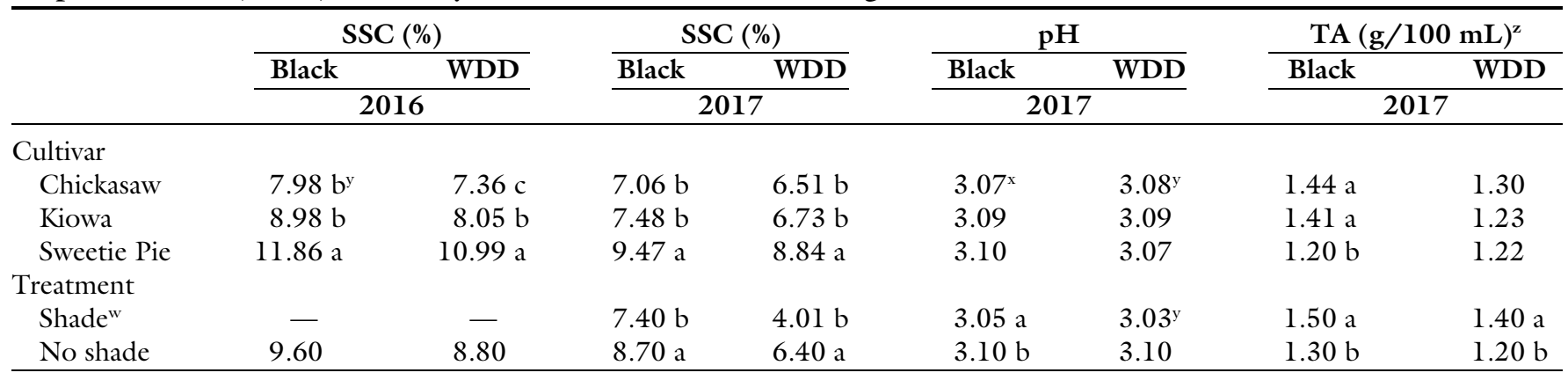

${ }^{\mathrm{z}} 1 \mathrm{~g} / 100 \mathrm{~mL}=1 \%$.

${ }^{y}$ Means within a column not followed by the same letter are significantly different as determined by Tukey's honestly significant difference at $P \leq 0.05$.

${ }^{\mathrm{x}}$ Not significant.

"Values are the average of all three cultivars grown in each treatment for only 2017. 
appears that shade treatment not only decreased soluble solids concentration and $\mathrm{pH}$ in all cultivars, but also increased TA. Increased level of TA in response to lower irradiance has been reported for grape (Bergqvist et al., 2001; Smart et al., 1988), tomato [Solanum lycopersicum (El-Gizawy et al., 1992)], and pineapple [Ananas comosus (Medina et al., 1993)]. The higher TA in shaded berries due to accumulation of citric acid, malic acid, or both, or increased acid degradation because of the higher temperatures of exposed fruit to sunlight in grape have been reported previously (Lakso and Kliewer, 1978; Morrison, 1988).

LEAF CHLOROPHYLL. Shade treatment had a significant effect on chlorophyll index (SPAD) of plants. Although there was no significant difference in SPAD among cultivars $(P=0.32)$, the SPAD value of three cultivars grown under shade was significantly higher compared with non-shaded plants; 50.6 and 48.3 , respectively $(P<0.0001)$. These results could be partially due to photooxidation of chlorophyll in plants grown under high light intensity (Minkov et al., 1999). The increase in chlorophyll index in response to low light intensity has been reported in saba nut [Bombacopsis glabra (Scalon et al., 2003)] and mangium [Acacia mangium (Almeida et al., 2005)]. Based on our observations, there were more berries with white drupelets near the ground than in the top of the plant, but reasons for this are still unclear.

\section{Conclusions}

Our results show the importance of environmental factors on WDD occurrence. However, more research is needed to discover the underlying causes of WDD. Plant nutrition is another area to be explored as a potential modifier of WDD manifestation as suggested by Quezada et al. (2007) who found that white drupelets decreased with an increase in nitrogen application rate in 'Heritage' red raspberry (Rubus ideaus). This study showed that potentially up to $22 \%$ of berries in a certain cultivar could be affected by this disorder. Rain and the shadecloth treatment decreased symptoms of WDD in this study; therefore, overhead irrigation and shade may correspondingly reduce WDD symptoms.

\section{Literature cited}

Almeida, S.M.Z., A.M. Soares, A.M.D. Castro, C.V. Vieira, and E.B. Gajego. 2005. Morphologic alterations and biomass allocation in young plants of forestry species under different conditions of shading. Cienc. Rural 35:62-68.

Bassman, J.H. 2004. Ecosystem consequences of enhanced solar ultraviolet radiation: Secondary plant metabolites as mediators of multiple trophic interactions in terrestrial plant communities. Photochem. Photobiol. 79:382-398.

Beggs, C.J. and E. Wellmann. 1994. Photocontrol of flavonoid biosynthesis, p. 733-751. In: R.E. Kendrick and G.H. M. Kronenberg (eds.). Photomorphogenesis in plants. Springer, Dordrecht, The Netherlands.

Benvenuti, S., F. Pellati, M. Melegari, and D. Bertelli. 2004. Polyphenols, anthocyanins, ascorbic acid, and radical scavenging activity of Rubus, Ribes, and Aronia. J. Food Sci. 69:FCT164-FCT169.

Bergqvist, J., N. Dokoozlian, and N. Ebisuda. 2001. Sunlight exposure and temperature effects on berry growth and composition of Cabernet Sauvignon and Grenache in the central San Joaquin Valley of California. Amer. J. Enol. Viticult. 52:1-7.

Bolda, M. 2009. Caneberries. White drupelet. 27 Oct. 2017. <http://www.ipm. ucdavis.edu/PMG/r71800111.html>.

Burger, J. and G.E. Edwards. 1996. Photosynthetic efficiency, and photodamage by UV and visible radiation, in red versus green leaf coleus varieties. Plant Cell Physiol. 37:395-399.

Clark, J.R. 2008. Musings on white drupelet and the 2008 season. Bramble 23(2):5-7.

Clark, J.R. 2013. Thoughts on white drupes on blackberries. Arkansas Fruit Nut News 3(4):1-2.

Clark, J.R. and J.N. Moore. 1999. 'Chickasaw' blackberry. HortScience 34:1294-1296.

Dodd, I.C., C. Critchley, G.S. Woodall, and G.R. Stewart. 1998. Photoinhibition in differently coloured juvenile leaves of Syzygium species. J. Expt. Bot. 49:1437-1445.

El-Gizawy, A.M., M.M.F. Abdallah, H.M. Gomaa, and S.S. Mohamed. 1992. Effect of different shading levels on tomato plants. 2. Yield and fruit quality. Acta Hort. 323:349-354.

Fernandez, G. 2012. White (grey or tan) drupelets. Team Rubusblog. 27 Oct. 2017. <http://teamrubus.Blogspot.com/2012/ $05 /$ white-grey-or-tan-drupelets.html $>$.
Hada, M., S. Tsurumi, M. Suzuki, E. Wellmann, and T. Hashimoto. 1996. Involvement and non-involvement of pyrimidine dimer formation in UV-B effects on Sorghum bicolor Moench seedlings. J. Plant Physiol. 148:92-99.

Hatier, J.H.B., M.J. Clearwater, and K.S. Gould. 2013. The functional significance of black-pigmented leaves: Photosynthesis, photo-protection, and productivity in Ophiopogon planiscapus 'Nigrescens'. PLoS One 8:e67850.

Hughes, N.M., K.O. Burkey, J. CavendarBares, and W.K. Smith. 2012. Xanthophyll cycle pigment and antioxidant profiles of winter-red (anthocyanic) and winter-green (acyanic) angiosperm evergreen species. J. Expt. Bot. 63:1895-1905.

Lakso, A.N. and W.M. Kliewer. 1978. The influence of temperature on malic acid metabolism in grape berries. II. Temperature responses of net dark $\mathrm{CO}_{2}$ fixation and malic acid pools. Amer. J. Enol. Viticult. 29:145-149.

Medina, E., M. Popp, E. Olivares, H.P. Janett, and U. Lüttge. 1993. Daily fluctuations of titratable acidity, content of organic acids (malate and citrate) and soluble sugars of varieties and wild relatives of Ananas comosus L. growing under natural tropical conditions. Plant Cell Environ. 16:55-63.

Minkov, I.N., G.T. Jahoubjan, I.D. Denev, and V.T. Toneva. 1999. Photooxidative stress in higher plants, p. 499-525. In: M. Pessarakli (ed.). Handbook of plant and crop stress. Marcel Dekker, New York, NY.

Moore, J.N. and J.R. Clark. 1996. 'Kiowa' blackberry. HortScience 31:286-288.

Moorthy, P. and K. Kathiresan. 1997. Influence of ultraviolet- $B$ radiation on photosynthetic and biochemical characteristics of a mangrove Rhizophoru apiculura. Photosynthetica 34:465-471.

Morrison, J.C. 1988. The effects of shading on the composition of Cabernet Sauvignon grape berries, p. 144-146. In: R. Smart, R. Thornton, S. Rodriquez, and J. Young (eds.). Proc. 2nd Intl. Symp. Cool Climate Viticult. Oenol. 11-15 Jan. 1988. Auckland, New Zealand.

Oren-Shamir, M. and A. Levi-Nissim. 1997. Temperature effects on the leaf pigmentation of Cotinus coggygria 'Royal Purple'. J. Hort. Sci. 72:425-432.

Quezada, C., I. Vidal, L. Lemus, and H. Sanchez. 2007. Effect of nitrogen fertilization on yield and fruit quality of raspberries (Rubus idaeus L.) under two fertigation programs. J. Soil Sci. Plant Nutr. 7(3):1-15.

Reddy, V.S., K.V. Goud, R. Sharma, and A. R. Reddy. 1994. Ultraviolet-B-responsive 
anthocyanin production in a rice cultivar is associated with a specific phase of phenylalanine ammonia lyase biosynthesis. Plant Physiol. 105:1059-1066.

Ruhl, G. 2010. White drupelets on raspberries and blackberries. P\&PDL picture of the week for 6 Sept. 2010. 27 Oct. 2017. <https://ag.purdue.edu/btny/ ppdl/Pages/POTW_old/9-6-10.html>.

Salgado, A.A. and J.R. Clark. 2016. "Crispy" blackberry genotypes: A breeding innovation of the University of Arkansas blackberry breeding program. HortScience 51:468-471.

Scalon, S.P.Q., R.M. Mussury, M.R. Rigoni, and H. Scalon. 2003. Initial growth of Bombacopsis glabra (Pasq.) A. Robyns seedlings under shading conditions. Rev. Arvore 27:753-758.
Sellappan, S., C.C. Akoh, and G. Krewer. 2002. Phenolic compounds and antioxidant capacity of Georgia-grow blueberries and blackberries. J. Agr. Food Chem. 50:2432-2438.

Smart, R.E., S.M. Smith, and R.V. Winchester. 1988. Light quality and quantity effects on fruit ripening for Cabernet Sauvignon. Amer. J. Enol. Viticult. 39:250-258.

Solovchenko, A. 2010. Localization of screening pigments within plant cells and tissues, p. 67-88. In: B. Martinac (ed.). Photoprotection in plants. Springer series in biophysics, Vol. 14. Springer, Berlin, Germany.

Spiers, J.D., J.A. Pitts, R.T. Boozer, and J.R. Clark. 2014. Influence of high tunnel and shade on blackberry yield and white drupelet disorder. HortScience 49:S405 (abstr.).

Steyn, W.J., D.M. Holcroft, S.J.E. Wand, and G. Jacobs. 2004. Anthocyanin degradation in detached pome fruit with reference to preharvest red color loss and pigmentation patterns of blushed and fully red pears. J. Amer. Soc. Hort. Sci. 129:13-19.

Stringer, S.J., B.J. Smith, B.J. Sampson, D. A. Marshall-Shaw, and J.J. Adamczyk. Jr., 'Sweetie Pie' thornless semi-erect blackberry. J. Amer. Pomol. Soc. (in press).

Takeda, F., D.M. Glenn, and T. Tworkoski. 2013. Rotating cross-arm trellis technology for blackberry production. J. Berry Res. 3:25-40. 